\title{
Deviations from Optimal Corporate Cash Holdings and the Valuation from a Shareholder's Perspective
}

\author{
Zhenxu Tong * \\ University of Exeter
}

\begin{abstract}
The tradeoff theory of corporate cash holdings predicts that there is an optimal level of cash. We test the tradeoff theory by investigating the relation between deviations from optimal cash holdings and the valuation of cash from a shareholder's perspective. We decompose corporate cash holdings into the optimal level of cash and the deviations from the optimum. We find that the marginal value of cash for shareholders is higher when a change in cash moves corporate cash holdings towards the optimal level, and that this relationship holds for both the above-optimal deviations and the below-optimal deviations. We conclude that the results are consistent with the prediction of the tradeoff theory of corporate cash holdings.
\end{abstract}

JEL Classification: G30; G32

Keywords: Corporate cash holdings; Tradeoff theory

\footnotetext{
* Address: Finance Department, School of Business, University of Exeter, Exeter EX4 4ST, UK. Telephone: +44 1392 723155. E-mail address: z.tong@exeter.ac.uk. This work was supported by the KPMG Global Valuation Institute Research Grant.
} 


\section{Introduction}

Theories have been proposed to explain why firms hold cash. A key difference among different theories is the prediction about whether there is an optimal level of corporate cash holdings. The tradeoff theory predicts that there is an optimal level of cash based on the tradeoff between the benefits and the costs of holding cash (e.g., Kim et al., 1998; Opler et al., 1999), while the financing hierarchy theory and the agency theory predict that there is not such an optimal level (e.g., Opler et al., 1999).

In this paper, we empirically test the tradeoff theory of corporate cash holdings by examining whether there is an optimal level of cash holdings. While the tradeoff theory predicts that there is an optimal level of cash, the actual level of cash may not always stay at the optimal point. Suppose there is a deviation from the optimal level of cash, we expect that the deviations reduce the value of cash to shareholders.

We get a sample of 77999 firm-year observations from 1985 to 2005 . We use a two-step methodology. First, we use a benchmark specification for the determinants of corporate cash holdings based on Opler et al. (1999). The predicted level of cash is regarded as the optimal level of cash. The residuals are regarded as the deviations from the optimum. Then we use the methodology based on Faulkender and Wang (2006) to examine how the deviations from the optimum affect the marginal value of cash to shareholders.

We find that the deviations from optimal cash holdings reduce the value of cash to shareholders. The marginal value of one dollar is $\$ 1.14$ (\$0.97) if a change in cash moves corporate cash holdings towards (away from) the optimal level. It implies that on average the same dollar is valued at a difference of 17 cents depending on whether it increases or reduces the magnitude of deviations from the optimum. We examine the deviations on either side of the optimal level of cash, and find that both the 
above-optimal deviations and the below-optimal deviations reduce the marginal value of cash to shareholders. We find consistent results when we use different measures of the magnitude of deviations from the optimum.

We conclude that the results are consistent with the prediction of the tradeoff theory, and that there exists an optimal level of corporate cash holdings.

This paper contributes to the literature on corporate cash holdings by providing more explicit evidences to support the tradeoff theory. Previous papers in the literature argue that it is difficult to differentiate the tradeoff theory from alternative theories. For example, Opler et al. (1999) examine the determinants of corporate cash holdings, and state that "the distinction between the financing hierarchy model and the static tradeoff model is not as clear-cut as one might want". ${ }^{1}$ They argue that "Even though we focus on an extreme version of the financing hierarchy model, some of its empirical predictions are similar to those of the static tradeoff model, so that it is difficult to distinguish empirically between the two models". ${ }^{2}$

Our paper differs from the papers in the literature in that we test the tradeoff theory by examining how the deviations from the optimum affect the value of cash. Since the tradeoff theory predicts that there is an optimal level of cash, we develop the hypothesis based on the conjecture that the deviations from the optimum reduce the value of cash to shareholders. This is a unique prediction of the tradeoff theory, and is not shared by any other theory on corporate cash holdings. Therefore, since our research setting is not affected by the potential confounding interpretation from the alternative theories, our results can provide more explicit evidences to support the tradeoff theory.

\footnotetext{
1 See Opler et al. (1999), p14.

2 See Opler et al. (1999), p14.
} 


\section{Hypothesis development}

Opler et al. (1999) propose a tradeoff theory of corporate cash holdings. The tradeoff theory argues that there is an optimal level of cash. Cash holdings are determined by the tradeoff between the costs and the benefits of carrying cash. The costs of holding cash include lower rate of returns and tax disadvantages. The benefits of holding cash include reducing transaction costs and retaining the ability to finance investment projects when external financing is too costly. Corporate cash holdings should be held at the point where the marginal benefit equals the marginal cost of holding cash.

However, the actual level of cash may not always stay at the optimal point. Therefore, we can decompose the actual level of cash into two parts: the optimal level of cash and the deviations from the optimum. This can be illustrated by Figure 1. In this figure, Point $\mathrm{C}$ indicates the value-maximizing point of cash holdings. Point $\mathrm{A}$ represents the situation of a below-optimal deviation, and Point B represents the situation of an above-optimal deviation.

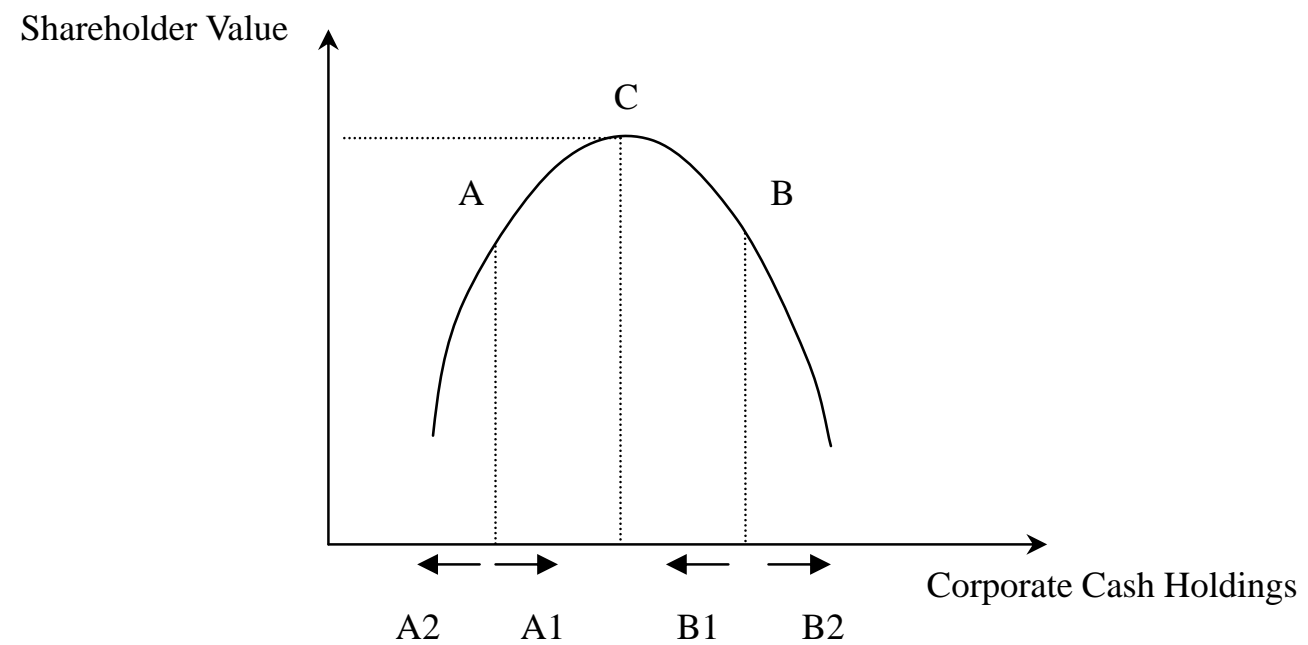

Figure 1 
Moreover, in the Figure 1, Arrow A1 and Arrow B1 indicate that a change in cash moves corporate cash holdings towards the optimal level. Conversely, Arrow A2 and Arrow B2 indicate that a change in cash moves corporate cash holdings away from the optimal level. We expect that shareholders place a higher (lower) value on cash if a change in cash moves cash holdings towards (away from) the optimal level.

Therefore, we have the following hypothesis.

Hypothesis 1: The marginal value of cash is higher (lower) for shareholders when a change in cash moves corporate cash holdings towards (away from) the optimal level.

\section{Data and methodology}

We describe the data and the methodology in this section.

\subsection{Data}

We obtain the data of U.S. firms in Compustat from 1985 to 2005. We obtain stock return data from CRSP. We get the data of the institutional ownership from the Thomson Financial Institutional Ownership database. We get the segment-level data from the Compustat Segment database. We obtain the data of GDP from the website of the Federal Reserve Bank. We obtain the data of 25 Fama and French portfolios formed on size and book-to-market from Professor Kenneth French's website. ${ }^{3}$ We exclude financial service firms (SIC codes between 6000 and 6999), because their cash holdings need to meet statutory capital requirements. We merge the data from these databases and exclude the firms with incomplete data. Our final sample consists of 10264 firms with 77999 firm-year observations. We winsorize the data to reduce the impact of outliers.

\footnotetext{
${ }^{3}$ http://mba.tuck.dartmouth.edu/pages/faculty/ken.french/data_library.html.
} 
Table 1 shows the univariate statistics. We find that the mean of the ratio of cash to net assets (defined as total assets less cash) is 0.2271 , and the median is 0.0803 . It is consistent with the findings in Opler et al. (1999) and Bates et al. (2009) that corporate cash holdings have an important role in a firm's balance sheet due to its magnitude.

\subsection{Methodology}

We follow Tong (2008) and use a two-step methodology.

\subsubsection{First step}

In the first step, we design a benchmark specification for the determinants of corporate cash holdings based on Opler et al. (1999) as well as the papers in the more recent literature (e.g., Harford et al., 2012; Subramaniam et al., 2011). We estimate the following regression using the Fama-MacBeth method ${ }^{4}$.

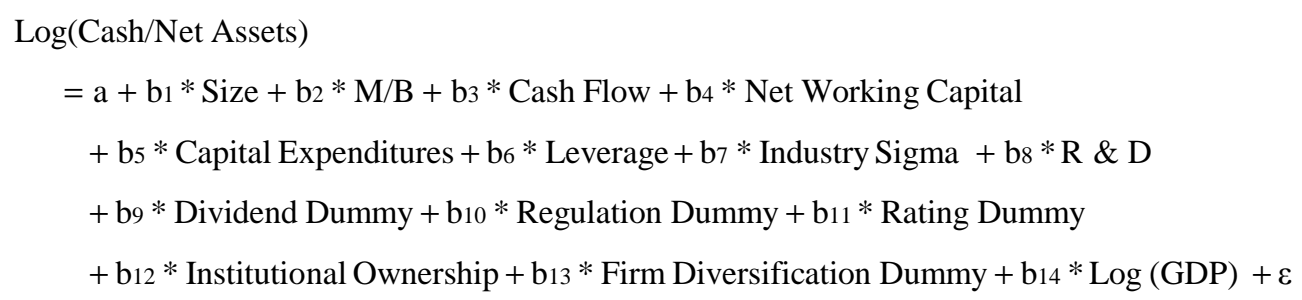

\subsubsection{The variables in the equation (1)}

In this section, we describe the variables in the equation (1).

\section{(1) The dependent variable}

We follow Opler et al. (1999) and use the logarithm of the ratio of Cash to Net Assets as the dependent variable. Cash is cash and marketable securities, and Net Assets is total assets less cash.

\footnotetext{
4 The Fama-MacBeth method treats each year as an independent cross-section and mitigates the problem of serial correlation in the residuals of a time-series cross-sectional regression. See Fama and MacBeth (1973) for more details.
} 
(2) Size

Size is the logarithm of net assets. Miller and Orr (1966) suggest that there are economies of scale in cash management. The tradeoff theory predicts that firm size has a negative impact on cash holdings because of the economies of scale.

\section{(3) Market-to-book ratio}

$\mathrm{M} / \mathrm{B}$ is the market-to-book ratio. It is calculated as the market value of equity plus the book value of net assets minus the book value of common equity, divided by net assets. Opler et al. (1999) state that "The market-to-book ratio is often used as a proxy

for investment opportunities". 5 The tradeoff theory predicts that a firm with higher investment opportunities holds more cash because the firm will have to give up better projects if faced with a cash shortage.

\section{(4) Cash flow}

Cash flow is the ratio of income before extraordinary items to net assets. The tradeoff theory predicts that firms with higher cash flow can afford to keep lower levels of cash because higher cash flow can better meet a firm's demand for liquidity.

\section{(5) Net working capital}

Net Working Capital is working capital less cash, divided by net assets. Opler et al. (1999) argue that a firm may hold alternative liquid assets besides cash, and use the net working capital as a measure of liquid asset substitutes.

\section{(6) Capital expenditures}

Capital Expenditures are the ratio of capital expenditures to net assets. The tradeoff theory predicts that firms with more capital expenditures hold more cash because a firm has more demand for the liquidity.

\footnotetext{
${ }^{5}$ See Opler et al. (1999), p11-p12.
} 


\section{(7) R\&D}

$\mathrm{R} \& \mathrm{D}$ is the ratio of research and development expenses to net assets. The same argument for the capital expenditures applies to the R\&D.

\section{(8) Leverage}

Leverage is the ratio of long-term debt to net assets. The tradeoff theory predicts that firms with higher leverage have more cash because there is higher agency cost of debt associated with higher leverage.

\section{(9) Industry sigma}

Industry sigma is a measure of the industry volatility, and is defined as the mean of standard deviations of cash flow over assets over the previous 5 years for the firms in the same industry as defined by 2 -digit SIC code. The tradeoff theory predicts that the firms in an industry with greater volatility hold more cash because the uncertainty may lead to the situations in which firms have more outlays than expected.

\section{(10) Dividend dummy}

Dividend dummy is a dummy variable that equals 1 if a firm pays dividends, and equals 0 otherwise. The tradeoff theory predicts that firms have more cash if they pay dividends because a firm that currently pays dividends can reduce its dividend payments and converted them into cash at low cost.

\section{(11) Regulation dummy}

Regulation dummy is dummy variable that equals 1 if a firm is in a regulated industry, and equals 0 otherwise. This controls for the potential effects of regulation.

\section{(12) Institutional ownership}

Institutional Ownership is the ratio of the shares owned by institutional investors to the total shares outstanding. Harford et al. (2012) find that firms with weaker corporate governance structures have smaller cash reserves. We use institutional 
ownership as a measure of corporate governance. ${ }^{6}$ A higher level of institutional ownership indicates better corporate governance.

\section{(13) Firm diversification dummy}

Firm Diversification Dummy is a dummy variable that equals 1 if a firm has at least two segments with different 2-digit SIC codes, and 0 otherwise. Opler et al. (1999) argue that the tradeoff theory predicts that diversified firms have less cash than specialized firms because diversified firms are more likely than specialized firms to have substantial assets that can be sold. Subramaniam et al. (2011) find that diversified firms hold less cash than focused firms.

\section{(14) $\log ($ GDP)}

$\log (\mathrm{GDP})$ is the logarithm of the Gross Domestic Product at the quarter immediately before a firm's fiscal-year-end month. We use this variable as a measure of the economic environmental conditions.

\subsubsection{The variable Towards Optimum}

In the equation (1), the predicted level of cash is regarded as the optimal level of cash. The residuals are regarded as the deviations from the optimum, because the residuals are not explained by the determinants of corporate cash holdings. We construct a dummy variable called Towards Optimum. This is a measure that indicates whether or not a change in cash will move corporate cash holdings towards the optimum.

\footnotetext{
${ }^{6}$ Harford et al. (2012) also use other measures of corporate governance, such as the Gindex developed by Gompers et al. (2003), board characteristics, and so on. However, these measures are only available for a sub-sample of the firms (mostly larger firms). Since we need to estimate a benchmark model for the entire sample, we use institutional ownership as a measure of corporate governance.
} 
The variable Towards Optimum is defined as follows.

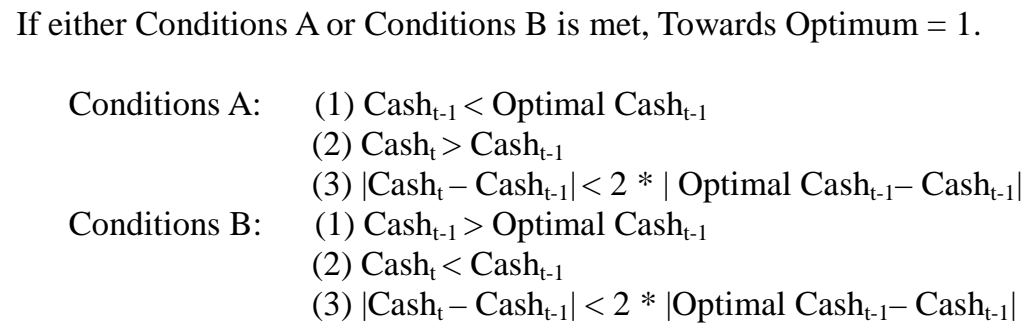

Otherwise, Towards Optimum $=0$.

Conditions A include three conditions. First, a firm's actual level of cash at year $\mathrm{t}-1$ is below the optimal level of cash at year t-1 (i.e., below-optimal deviations). Second, the firm's cash at year t is greater than its cash at year t-1 (i.e., an increase in cash holdings). Third, the absolute value of the change in cash from year $t-1$ to $t$ is less than twice of the difference between a firm's actual level of cash and optimal level of cash at year $\mathrm{t}-1$. If these three conditions are met, then the change in cash from year $\mathrm{t}-1$ to year $\mathrm{t}$ moves corporate cash holdings towards the optimal level. Here, the third condition means that an increase in cash is not too large to ensure that the increase in cash will reduce the difference between a firm's actual level of cash and the optimum.

Similarly, Conditions B include three conditions. First, a firm's actual level of cash at year t-1 is above the optimal level of cash at year t-1 (i.e., above-optimal deviations). Second, the firm's cash at year t is less than its cash at year t-1 (i.e., an decrease in cash holdings). Third, the absolute value of the change in cash from year $\mathrm{t}-1$ to $\mathrm{t}$ is less than twice of the difference between a firm's actual level of cash and optimal level of cash at year $\mathrm{t}-1$. If these three conditions are met, then the change in cash from year t-1 to year t moves corporate cash holdings towards the optimal level.

If neither Conditions A nor Conditions B is met, then the change in cash from year $\mathrm{t}-1$ to year $\mathrm{t}$ moves corporate cash holdings away from the optimal level. 


\subsubsection{Second step}

In the second step, we study how a change in cash affects shareholder value depending on whether or not the change in cash moves corporate cash holdings towards the optimum. This model is based on a benchmark model proposed by Faulkender and Wang (2006). The methodology in Faulkender and Wang (2006) essentially represents a long-run event study. The event is the unexpected change in cash holdings, while the event window is defined as the whole fiscal year.

$$
\begin{aligned}
& \mathrm{R}_{\mathrm{i}, \mathrm{t}}-\mathrm{RB}_{\mathrm{i}, \mathrm{t}}=\mathrm{a}+\mathrm{b}_{1} * \frac{\Delta \mathrm{Cash}_{\mathrm{i}, \mathrm{t}}}{\mathrm{MV}_{\mathrm{i}, \mathrm{t}-1}}+\mathrm{b}_{2} * \text { Towards Optimumi, } \mathrm{t}^{2} \frac{\Delta \mathrm{Cash}_{\mathrm{i}, \mathrm{t}}}{\mathrm{MV}_{\mathrm{i}, \mathrm{t}-1}} \\
& +\mathrm{b}_{3} * \frac{\Delta \text { Earningsi } \mathrm{t}}{\mathrm{MV}_{\mathrm{i}, \mathrm{t}-1}}+\mathrm{b}_{4} * \frac{\Delta \text { Net Assetsi } \mathrm{t}}{\mathrm{MV}_{\mathrm{i}, \mathrm{t}-1}}+\mathrm{b}_{5} * \frac{\Delta \mathrm{R} \& \mathrm{D}_{\mathrm{i}, \mathrm{t}}}{\mathrm{MV}_{\mathrm{i}, \mathrm{t}-1}}+\mathrm{b}_{6} * \frac{\Delta \text { Interest Expensesi } \mathrm{t}^{-1}}{\mathrm{MV}_{\mathrm{i}, \mathrm{t}-1}}
\end{aligned}
$$

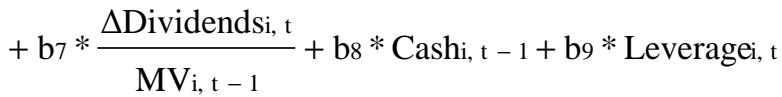

$$
\begin{aligned}
& +\mathrm{b}_{10} * \mathrm{Cash}_{\mathrm{i}, \mathrm{t}-1} * \frac{\Delta \mathrm{Cash}_{\mathrm{i}, \mathrm{t}}}{\mathrm{MV}_{\mathrm{i}, \mathrm{t}-1}}+\mathrm{b}_{11} * \text { Leverage }, \mathrm{t}^{\mathrm{a}} * \frac{\Delta \mathrm{Cash}_{\mathrm{i}, \mathrm{t}}}{\mathrm{MV}_{\mathrm{i}, \mathrm{t}-1}} \\
& +\mathrm{b}_{12} * \frac{\text { Net Financing }_{\mathrm{i}, \mathrm{t}}}{\mathrm{MV}_{\mathrm{i}, \mathrm{t}-1}}+\varepsilon_{\mathrm{i}, \mathrm{t}}
\end{aligned}
$$

We describe the variables in the equation (2) as follows.

\section{(1) The dependent variable}

The dependent variable is excess stock return. It is calculated as the stock return of firm i during a fiscal year $t\left(\mathrm{R}_{\mathrm{i}, \mathrm{t}}\right)$ minus its benchmark return over the same period $\left(\mathrm{RB}_{\mathrm{i}, \mathrm{t}}\right)$. The benchmark portfolio is one of the 25 Fama and French portfolios formed on size and book-to-market. ${ }^{7}$

\section{(2) The unexpected change in cash holdings: $\Delta$ Cash}

We follow the methodology in Faulkender and Wang (2006) and first define the

\footnotetext{
${ }^{7}$ For each firm-year observation, a firm is grouped into one of the 25 Fama and French portfolios based on the intersection between size and book-to-market. The return of the corresponding Fama and French portfolio is regarded as the benchmark return for the firm during that year. See Faulkender and Wang (2006) for more details.
} 
unexpected change in cash holdings as the realized change in cash holdings. Then we use an alternative measure based on the net change in cash holdings in the later analysis. We measure the change in cash holdings as the ratio of the change in cash and marketable securities over a fiscal year to the 1-year lagged market value of equity.

\section{(3) The interaction item: Towards Optimum * $\Delta$ Cash}

We construct an interaction term, Towards Optimum $* \Delta$ Cash. The variable Towards Optimum is obtained from the first step. According to the Hypothesis 1, we expect that the coefficient of this interaction term is positive, which indicates that the marginal value of cash is higher if a change in cash moves corporate cash holdings towards the optimal level.

\section{(4) Control variables}

We follow Faulkender and Wang (2006) and include the following control variables. The first group of variables control for the firm-specific factors that might be correlated with the unexpected change in cash holdings. These variables include the change in the interest expenses ( $\Delta$ Interest Expenses), the change in dividends ( $\Delta$ Dividends), the lagged cash holdings $\left(\mathrm{Cash}_{\mathrm{t}-1}\right)$, the leverage (Leverage), and a firm's net financing defined as equity issued minus repurchases plus debt issued minus debt retired (Net Financing).

The second group of variables control for the change in profitability and corporate investment policies. These variables include the change in earnings ( $\Delta$ Earnings), the change in a firm's investment policies measured by the change in net assets $(\Delta \mathrm{Net}$ Assets) and the change in the $R \& D(\Delta R \& D)$.

The third group of variables control for other sources that can affect the marginal value of cash. These variables are two interaction items developed by Faulkender and 
Wang (2006): Leverage $* \Delta$ Cash and Cash $_{\mathrm{t}-1} * \Delta$ Cash. Faulkender and Wang (2006) argue that an extra dollar of cash holdings is less valuable for shareholders in highly levered firms than in firms with low leverage, and that the marginal value of cash is decreasing in the level of the firm's cash position. ${ }^{8}$

\subsubsection{About the joint-test argument}

We follow Tong (2008) and rely on a joint-test argument to validate the results. Suppose the first-step specification does not provide a proper description of the determinants of corporate cash holdings, it is more likely that the residuals are just noises so that they will not have a systematic relation with shareholder value as predicted by the tradeoff theory in the second-step analysis. However, suppose we do find that a change in cash is valued higher by shareholders if it moves corporate cash holdings towards the optimum, then this can in turn imply that the first-step specification gives a reasonable description of the determinants of corporate cash holdings and support the predictions of the tradeoff theory.

\section{Results}

We report the results in this section.

\subsection{Determinants of corporate cash holdings}

Table 2 shows the Fama-MacBeth model on the determinants of corporate cash holdings. We report the p-value calculated based on the Newey-West adjustment for standard errors. We find that cash increases with a firm's market-to-book ratio, earnings, capital expenditures, industry sigma, $R \& D$, institutional ownership, and the logarithm of GDP. We find that cash decreases with a firm's size, net working capital,

\footnotetext{
${ }^{8}$ See Faulkender and Wang (2006), p1963-p1964 and p1968.
} 
leverage, dividend dummy, regulation dummy, rating dummy, and firm diversification dummy. The signs of the coefficients are consistent with the findings in the literature. We construct the dummy variable Towards Optimum based on the estimates in this model.

\subsection{Deviations from the optimum and the value of cash}

Table 3 shows how the deviations from the optimum affect the value of cash to shareholders. We report the p-value calculated based on the robust standard errors clustered by firm (e.g., Petersen, 2009). We examine the marginal value of cash holdings in the entire sample, and report the results in the first column. In this regression, an extra dollar in cash affects a firm's excess return through the item $\Delta$ Cash and the interaction terms $\left(\mathrm{Cash}_{\mathrm{t}-1} * \Delta \mathrm{Cash}\right.$ and Leverage $\left.* \Delta \mathrm{Cash}\right)$. The calculation is as follows: The mean firm has a lag of cash holdings equivalent to $15.13 \%$ of the market capitalization of equity, and the mean leverage ratio, defined as the sum of long-term debt and debt in current liabilities divided by total assets, is 23.09\%. Therefore, the marginal value of one dollar to shareholders in the mean firm is $\$ 1.00(=1.392+(-1.348 * 15.13 \%)+(-0.809 * 23.09 \%))$.

In the second column of Table 3, we report the results about the impact of a change in the deviations of a firm's cash from the optimum on shareholder value. This regression follows the specification as indicated in the equation (2). To calculate the marginal value of cash holdings for shareholders when a change in cash moves corporate cash holdings away from the optimum, we use the coefficients of the same three items as before ( $\Delta \mathrm{Cash}, \mathrm{Cash}_{\mathrm{t}-1} * \Delta \mathrm{Cash}$, and Leverage $\left.* \Delta \mathrm{Cash}\right)$. We find that the marginal value of one dollar to shareholders is $\$ 0.97$ when a change in cash moves corporate cash holdings away from the optimum. To calculate the marginal value of cash holdings for shareholders when a change in cash moves corporate cash 
holdings towards the optimum, we use an additional coefficient of the interaction term, Towards Optimum * $\Delta$ Cash. Therefore, the marginal value of one dollar to shareholders when a change in cash moves corporate cash holdings towards the optimum is $\$ 1.14(=1.369+0.167+(-1.388 * 15.13 \%)+(-0.804 * 23.09 \%))$.

These results indicate that there is a significant difference in the marginal value of cash for shareholders depending on how a change in cash affects the deviations from the optimal level. An extra dollar is valued 17 cents more ( $\mathrm{p}$-value $=0.01)$ by shareholders when a change in cash moves corporate cash holdings towards the optimum. Therefore, the results in Table 3 are consistent with the Hypothesis 1.

\subsection{Alternative measure of the unexpected change in cash}

We follow Faulkender and Wang (2006) and repeat our analysis using the net change in cash holdings as an alternative measure of the unexpected change in cash. It is defined as the realized change in cash holdings minus the average change in cash holdings in the corresponding benchmark portfolio over the same period.

Table 4 shows the results. The first column demonstrates the regression for the entire sample. We find that the marginal value of one dollar to shareholders in the mean firm is $\$ 1.00$. The second column shows the regression when we include the interaction term Towards Optimum * $\Delta$ Net Cash. We find that the coefficient of the interaction term is 0.179 ( $\mathrm{p}$-value $=0.01)$, implying that the marginal value of cash is higher when a change in a firm's cash moves corporate cash holdings towards the optimal level. We therefore find similar results when we use the net change in cash.

\subsection{Both sides of deviations and the value of cash}

We investigate how the deviations on both sides of the optimum affect the value of cash to shareholders. We use a triple interaction term, Towards Optimum ${ }^{*} \Delta$ Cash * Above $_{\mathrm{t}-1}$, to conduct the analysis. Above $\mathrm{t}_{\mathrm{t}-1}$ is dummy variable that equals 1 if a 
firm's cash is above the optimal level at year t-1, and equals 0 otherwise.

Table 5 presents the results. The first column shows the regression when we use $\Delta$ Cash as the measure of the unexpected change in cash. When a change in cash moves corporate cash holdings away from the optimal level, an extra dollar is worth \$0.98 for shareholders. When a change in cash moves corporate cash holdings towards the optimal level if a firm's cash has been below (above) the optimal level, an extra dollar is worth $\$ 1.21(\$ 1.08)$ to shareholders.

We conduct an F-test on the null hypothesis that the sum of the coefficients of Towards Optimum $* \Delta$ Cash and Towards Optimum $* \Delta$ Cash $*$ Above $_{\mathrm{t}-1}$ is zero. This is to examine whether there is a significant difference in the value of cash between a change in cash that moves corporate cash holdings away from the optimum and a change in cash that moves corporate cash holdings towards the optimum when a firm's cash has been above the optimal level. We find that the difference is significant $(\mathrm{p}$-value $=0.01)$

The second column shows the regression when we use $\Delta$ Net Cash as the measure of the unexpected change in cash. We find that when a change in cash moves corporate cash holdings towards the optimal level if a firm's cash has been below (above) the optimal level, an extra dollar is worth $\$ 1.19$ (\$1.11) for shareholders. Therefore, we find consistent results. ${ }^{9}$

The results in Table 5 support the interpretation that the marginal value of cash is higher for shareholders in the situation when a change in cash moves corporate cash holdings towards the optimal level, no matter a firm's cash has been above or below the optimum, than the situation when a change in cash moves corporate cash holdings

\footnotetext{
${ }^{9}$ In the second column of Table 5, the coefficient of the triple interaction term Towards Optimum * $\Delta \mathrm{Net}$ Cash $*$ Above $_{\mathrm{t}-1}$ is insignificant. It implies that if a change in cash moves corporate cash holdings towards the optimum, there is not a significant difference in the marginal value of cash between the situation of above-optimal deviation and the situation of the below-optimal deviation.
} 
away from the optimal level. The findings are consistent with the Hypothesis 1 .

\subsection{The magnitude of deviations and the value of cash}

We examine the magnitude of deviations and the value of cash in this section. First, we construct two dummy variables called Larger Step Towards Optimum and Smaller Step Towards Optimum. The variable Larger (Smaller) Step Towards Optimum equals 1 if the magnitude of the change in cash towards the optimum is above (below) the median and equals 0 otherwise. Then we construct two triple interaction terms: Towards Optimum * Larger Step Towards Optimum * $\Delta$ Cash and Towards Optimum * Smaller Step Towards Optimum * $\Delta$ Cash.

The first column of Table 6 shows the results. We find that the coefficients of the two triple interaction term are $0.197(\mathrm{p}$-value $=0.01)$ and $0.116(\mathrm{p}$-value $=0.03)$, indicating that the marginal value of cash is higher if a change in cash moves corporate cash holdings towards the optimal level either in a larger magnitude or in a smaller magnitude. Moreover, we find that the marginal value of cash is higher in the situation of a larger step towards the optimum (\$1.17) than in the situation of a smaller step towards the optimum (\$1.09).

Second, we define a dummy variable called After Adjustment Close To Optimum. The variable equals 1 if a firm's cash is at most $10 \%$ away from the optimum after the change and equals 0 otherwise. ${ }^{10}$ Then we construct a triple interaction term: Towards Optimum * After Adjustment Close To Optimum * $\Delta$ Cash.

The second column of Table 6 shows the results. We find that the coefficient on this triple interaction term is positive and significant, indicating that the marginal value of cash is higher (\$1.66) if a firm's cash is close to the optimum after the change.

\footnotetext{
${ }^{10}$ We conduct the robustness check by using different cutoff points, and find similar results.
} 
Third, we use a continuous variable to replace the Towards Optimum dummy variable. The continuous variable is called Disequilibrium Reduction, and is defined as the reduction in the magnitude of deviations from the optimum. The calculation of the variable follows the similar rationale as the calculation for the Towards Optimum dummy variable as discussed in the Methodology section, but now we obtain the magnitude of the reduction in the deviations instead of just identifying the direction of the change in cash. The variable Disequilibrium Reduction is positive (negative) if a change in cash moves corporate cash holdings towards (away from) the optimum. We construct an interaction term: Disequilibrium Reduction $* \Delta$ Cash.

The third column of Table 6 shows the results. We find that the coefficient of the interaction term is $0.571(\mathrm{p}$-value $=0.01)$, indicating that the marginal value of cash is higher if a change in cash reduces the magnitude of deviations and moves corporate cash holdings towards the optimal level. An extra dollar is on average worth $\$ 1.14$ (\$0.98) for the situation of a positive (negative) Disequilibrium Reduction.

Therefore, we find consistent results when we use different measures of the magnitude of deviations from the optimum. The results in Table 6 support the Hypothesis 1.

\subsection{Sample period}

We conduct the robustness check on the sample period. Our sample period is 21 years and the ideas about the optimal level of cash may evolve over time. Therefore, we divide the sample into two periods and conduct the robustness checks. One period is from 1985 to 1995 , and the other period is from 1996 to 2005 . We estimate the benchmark specification for the determinants of cash holdings separately for the two sample periods (not reported for the brevity), and then examine the value of cash in the two sample periods. 
Table 7 shows the results. We find that the coefficient of the interaction term Towards Optimum $* \Delta$ Cash is $0.180(\mathrm{p}$-value $=0.01)$ for the sample period from 1985 to 1995 , and is 0.182 ( $\mathrm{p}$-value $=0.01)$ for the sample period from 1996 to 2005 . Therefore, we find similar results after we divide the sample into two periods.

\subsection{Alternative measure of the dependent variable}

We conduct the robustness check on the dependent variable. We construct an alternative measure of the dependent variable based on the Tobin's Q which is a classical measure of valuation. The variable is called Excess Change in Tobin's Q. We construct this variable by using the similar methodology as the one used for calculating the Excess Return. It can be expressed by the following equation.

Excess Change in Tobin's Q = Change in Tobin's Q - Benchmark Change in Tobin's Q

We first calculate the change in a firm's Tobin's $Q$ from t-1 to t. Then we calculate a benchmark change in Tobin's Q over the same period, calculated as the weighted average (weighted by firm size) of the change in Tobin's Q in one of the 25 Fama and French portfolios that the firm belongs to. The Excess Change in Tobin's Q is the difference between the change in a firm's Tobin's Q and the benchmark change in Tobin's Q.

Table 8 shows the results. The dependent variable is the Excess Change in Tobin's Q. The first column shows that the coefficient of the interaction term Towards Optimum $* \Delta$ Cash is 0.119 ( $\mathrm{p}$-value $=0.02)$. It implies that a change in cash have an additional positive impact on Tobin's $\mathrm{Q}$ if the change in cash moves corporate cash holdings towards the optimum. We examine the impact of the deviations on both sides in the second column. The second column shows that the coefficient of the interaction term Towards Optimum $* \Delta$ Cash is $0.131(\mathrm{p}$-value $=0.05)$, and that the coefficient of 
the triple interaction term Towards Optimum $* \Delta$ Cash $^{*}$ Above $_{\mathrm{t}-1}$ is -0.043 (p-value $=$ 0.79). We conduct an F-test on the null hypothesis that the sum of the coefficients of Towards Optimum * $\Delta$ Cash and Towards Optimum $* \Delta$ Cash $*$ Above $_{\mathrm{t}-1}$ is zero, and it rejects the null hypothesis $(\mathrm{p}$-value $=0.07)$. The results are consistent with the interpretation that a change in cash has an additional positive impact on Tobin's Q in the situation when a change in cash moves corporate cash holdings towards the optimal level, no matter a firm's cash has been above or below the optimum.

Therefore, we find similar results when we use an alternative measure of the dependent variable.

\section{Conclusion}

The tradeoff theory of corporate cash holdings predicts that there is an optimal level of corporate cash holdings. In this paper, we test the tradeoff theory by studying the relation between the deviations from optimal cash holdings and the valuation of cash from a shareholder's perspective. We use a two-step methodology. In the first step, we decompose corporate cash holdings into the optimal level of cash and the deviations from the optimal level. In the second step, we examine the value of cash for shareholders depending on how a change in cash affects the deviations from the optimal level. We find that the marginal value of cash for shareholders is higher when a change in cash moves corporate cash holdings towards the optimal level. Moreover, we find that the value of cash for shareholders is higher when a change in cash reduces the magnitude of either above-optimal deviations or below-optimal deviations. We conduct the robustness checks on the sample period and the dependent variable, and find similar results. 
We conclude that the results are consistent with the interpretation that there is an optimal level of corporate cash holdings, and that they support the tradeoff theory of corporate cash holdings.

From a practitioner's perspective, the findings in our paper can be beneficial for companies to better achieve the target of shareholder value maximization. Since our results support the tradeoff theory, it implies that a company can increase shareholder value by adjusting its corporate cash holdings towards the optimum. Suppose a firm has too few cash holdings, the firm can increase shareholder value by increasing its cash holdings towards the optimum. Suppose a firm has too many cash holdings, the firm can increase shareholder value by reducing its cash holdings towards the optimum. 


\section{References}

Bates, T., Kahle, K., Stulz, R., 2009, Why do U.S. firms hold so much more cash than they used to? Journal of Finance 64, 1985-2021.

Fama, E., MacBeth, J., 1973, Risk, return, and equilibrium: empirical tests, Journal of Political Economy 81, 607-636.

Faulkender, M., Wang, R., 2006, Corporate financial policy and the value of cash, Journal of Finance 61, 1957-1990.

Gompers, P., Ishii, J., Metrick, A., Corporate governance and equity prices, Quarterly Journal of Economics 118, 107-155.

Harford, J., Mansi, A., Maxwell, W., 2012, Corporate governance and firm cash holdings in the U.S., Corporate Governance, 107 - 138.

Kim, C., Mauer, D., Sherman, A., 1998, The determinants of corporate liquidity: theory and evidence, Journal of Financial and Quantitative Analysis 33, 335-59.

Miller, M., Orr. D., 1966, A model of the demand for money by firms, Quarterly Journal of Economics 80, 413-435.

Opler, T., Pinkowitz, L., Stulz, R., Williamson, R., 1999, The determinants and implications of corporate cash holdings, Journal of Financial Economics 52, 3-46.

Petersen, M., 2009, Estimating standard errors in finance panel data sets: Comparing approaches, Review of Financial Studies 22, 435-480.

Subramaniam, V., Tang, T., Yue, H., Zhou, X., 2011, Firm structure and corporate cash holdings, Journal of Corporate Finance 17, 759-773.

Tong, Z., 2008, Deviations from optimal CEO ownership and firm value, Journal of Banking and Finance 32, 2462-2470. 
Table 1

Univariate Statistics

This table reports univariate statistics. The sample consists of 77999 firm-year observations from 1985 to 2005. Cash is defined as cash and marketable securities divided by net assets, where net assets are total assets less cash. Size is defined as the logarithm of net assets. $M / B$ is defined as the market value of equity plus the book value of net assets minus the book value of common equity, divided by net assets. Cash Flow is defined as the ratio of income before extraordinary items to net assets. Capital Expenditures is defined as the ratio of capital expenditures to net assets. $R \& D$ is defined as the ratio of research and development expenses to net assets. Leverage is defined as the ratio of long-term debt to net assets. Dividends is defined as the ratio of common dividend to net assets. Net Working Capital is defined as working capital less cash, divided by net assets. Industry Sigma is the mean of standard deviations of cash flow over assets over the previous 5 years for the firms in the same industry as defined by 2-digit SIC code. Rating Dummy is a dummy variable that equals 1 if a firm's credit rating is at investment grades, and equals 0 otherwise. Institutional Ownership is the ratio of the shares owned by institutional investors to the total shares outstanding. Firm Diversification Dummy is a dummy variable that equals 1 if a firm has at least two segments with different 2-digit SIC codes, and 0 otherwise. GDP is the Gross Domestic Product at the quarter immediately before a firm's fiscal-year-end month.

\begin{tabular}{lccccc}
\hline & Mean & Median & $\begin{array}{c}\text { 25th } \\
\text { Percentile }\end{array}$ & $\begin{array}{c}\text { 75th } \\
\text { Percentile }\end{array}$ & Std. Dev. \\
\hline Cash & 0.2271 & 0.0803 & 0.0204 & 0.2925 & 0.3077 \\
Size & 18.6904 & 18.5501 & 17.0280 & 20.2707 & 2.3523 \\
M / B & 2.2663 & 1.4150 & 1.0646 & 2.3319 & 4.1265 \\
Cash Flow & -0.0239 & 0.0329 & -0.0450 & 0.0800 & 0.1939 \\
Capital Expenditures & 0.0764 & 0.0534 & 0.0269 & 0.0968 & 0.0767 \\
R\&D & 0.0684 & 0.0000 & 0.0000 & 0.0642 & 0.1375 \\
Leverage & 0.1905 & 0.1473 & 0.0103 & 0.3073 & 0.1927 \\
Dividends & 0.0091 & 0.0000 & 0.0000 & 0.0111 & 0.0194 \\
Net Working Capital & 0.0711 & 0.0852 & -0.0512 & 0.2596 & 0.2837 \\
Industry Sigma & 0.1039 & 0.0887 & 0.0551 & 0.1278 & 0.0746 \\
Rating Dummy & 0.0665 & 0.0000 & 0.0000 & 0.0000 & 0.2492 \\
Institutional Ownership & 0.2888 & 0.1970 & 0.0000 & 0.5197 & 0.2952 \\
Firm Diversification Dummy & 0.2949 & 0.0000 & 0.0000 & 1.0000 & 0.4560 \\
GDP & 8615.07 & 8402.00 & 6380.80 & 10644.30 & 2494.13 \\
\hline
\end{tabular}




\section{Table 2}

\section{Determinants of Corporate Cash Holdings}

This table reports the determinants of cash holdings using the Fama-MacBeth model over the period 1985 to 2005 . The definition of all the variables can be found in the text and in the heading of Table 1 . We report the p-value calculated based on the Newey-West adjustment for standard errors in the parentheses. $* * *, * *$ and $*$ denote significance at the $1 \%, 5 \%$ and $10 \%$ level.

\begin{tabular}{|c|c|}
\hline & Log (Cash) \\
\hline Intercept & $\begin{array}{c}-18.279 * \\
(0.06)\end{array}$ \\
\hline Size & $\begin{array}{c}-0.085^{* * *} \\
(0.01)\end{array}$ \\
\hline $\mathrm{M} / \mathrm{B}$ & $\begin{array}{c}0.217 * * * \\
(0.01)\end{array}$ \\
\hline Cash Flow & $\begin{array}{c}1.128 * * * \\
(0.01)\end{array}$ \\
\hline Capital Expenditures & $\begin{array}{c}0.799 * * * \\
(0.01)\end{array}$ \\
\hline $\mathrm{R} \& \mathrm{D}$ & $\begin{array}{c}2.571 * * * \\
(0.01)\end{array}$ \\
\hline Leverage & $\begin{array}{c}-1.027 * * * \\
(0.01)\end{array}$ \\
\hline Net Working Capital & $\begin{array}{r}-0.021 \\
(0.70)\end{array}$ \\
\hline Industry Sigma & $\begin{array}{c}2.165 * * * \\
(0.01)\end{array}$ \\
\hline Dividend Dummy & $\begin{array}{c}-0.160 * * * \\
(0.01)\end{array}$ \\
\hline Regulation Dummy & $\begin{array}{c}-0.163 * * * \\
(0.01)\end{array}$ \\
\hline Rating Dummy & $\begin{array}{c}-0.210 * * * \\
(0.01)\end{array}$ \\
\hline Institutional Ownership & $\begin{array}{c}0.284 * * * \\
(0.01)\end{array}$ \\
\hline Firm Diversification Dummy & $\begin{array}{c}-0.050 * * \\
(0.05)\end{array}$ \\
\hline $\log (\mathrm{GDP})$ & $\begin{array}{c}1.767 * \\
(0.08) \\
\end{array}$ \\
\hline Observations & 21 \\
\hline Adjusted R-squared & 0.35 \\
\hline
\end{tabular}




\section{Table 3}

\section{Deviations and the Value of Cash}

This table reports the relation between the deviations from optimal corporate cash holdings and the value of cash from a shareholder's perspective. The dependent variable is Excess Return defined as $\mathrm{R}_{\mathrm{i}, \mathrm{t}}$ - $\mathrm{RB}_{\mathrm{i}, \mathrm{t}}$. All variables except Excess Return, Towards Optimum, and Leverage are standardized by the lagged market value of equity. Cash is cash plus marketable securities. $\Delta$ Cash is the one-year change of cash holdings $\left(\mathrm{Cash}_{t}-\mathrm{Cash}_{t-1}\right)$. Towards Optimum is a dummy variable that equals 1 if the change in a firm's cash holdings reduces the difference between the actual level of cash and the predicted level of cash, and equals 0 otherwise. $\Delta$ Earnings is the one-year change of earnings before extraordinary items. $\Delta$ Net Assets is the one-year change of total assets minus cash holdings. $\Delta R \& D$ is the one-year change of research and development expenses. $\Delta$ Interest Expenses is the one-year change of interest expenses. $\Delta$ Dividends is the one-year change of common dividends. Leverage is the ratio of debt to total assets. Net Financing is net new equity issues plus net new debt issues. We report the p-value calculated based on the robust standard errors clustered by firm in the parentheses. $* * * * *$ and $*$ denote significance at the $1 \%, 5 \%$ and $10 \%$ level.

\begin{tabular}{|c|c|c|}
\hline \multirow[b]{2}{*}{ Intercept } & \multicolumn{2}{|c|}{ Excess Return } \\
\hline & $0.009 * *$ & $0.010 * *$ \\
\hline & $(0.04)$ & $(0.03)$ \\
\hline \multirow[t]{2}{*}{$\Delta$ Cash } & $1.392 * * *$ & $1.369 * * *$ \\
\hline & $(0.01)$ & $(0.01)$ \\
\hline \multirow[t]{2}{*}{ Towards Optimum $* \Delta$ Cash } & & $0.167 * * *$ \\
\hline & & $(0.01)$ \\
\hline \multirow[t]{2}{*}{$\Delta$ Earnings } & $0.701 * * *$ & $0.698 * * *$ \\
\hline & $(0.01)$ & $(0.01)$ \\
\hline \multirow[t]{2}{*}{$\Delta$ Net Assets } & $0.313 * * *$ & $0.315 * * *$ \\
\hline & $(0.01)$ & $(0.01)$ \\
\hline \multirow[t]{2}{*}{$\Delta \mathrm{R} \& \mathrm{D}$} & $0.744 * * *$ & $0.747 * * *$ \\
\hline & $(0.01)$ & $(0.01)$ \\
\hline \multirow[t]{2}{*}{$\Delta$ Interest Expenses } & $-1.507 * * *$ & $-1.509 * * *$ \\
\hline & $(0.01)$ & $(0.01)$ \\
\hline \multirow[t]{2}{*}{$\Delta$ Dividends } & $2.767 * * *$ & $2.767 * * *$ \\
\hline & $(0.01)$ & $(0.01)$ \\
\hline \multirow[t]{2}{*}{$\operatorname{Cash}_{\mathrm{t}-1}$} & $0.270 * * *$ & $0.276^{* * *}$ \\
\hline & $(0.01)$ & $(0.01)$ \\
\hline \multirow[t]{2}{*}{ Leverage } & $-0.268 * * *$ & $-0.270 * * *$ \\
\hline & $(0.01)$ & $(0.01)$ \\
\hline \multirow[t]{2}{*}{$\operatorname{Cash}_{\mathrm{t}-1} * \Delta$ Cash } & $-1.348 * * *$ & $-1.388 * * *$ \\
\hline & $(0.01)$ & $(0.01)$ \\
\hline \multirow[t]{2}{*}{ Leverage $* \Delta$ Cash } & $-0.809 * * *$ & $-0.804 * * *$ \\
\hline & $(0.01)$ & $(0.01)$ \\
\hline \multirow[t]{2}{*}{ Net Financing } & $0.128 * * *$ & $0.128 * * *$ \\
\hline & $(0.01)$ & $(0.01)$ \\
\hline Observations & 77999 & 77999 \\
\hline Adjusted R-squared & 0.12 & 0.12 \\
\hline
\end{tabular}
regressions.

The following table shows the marginal value of $\$ 1$ calculated based on the estimates in the

\begin{tabular}{ll|ll}
\hline \multicolumn{4}{c}{ The marginal value of \$1 } \\
\hline \multirow{2}{*}{$\$ 1.00$} & Towards Optimum $=1$ & $\$ 1.14$ \\
& Towards Optimum $=0$ & $\$ 0.97$ \\
\hline
\end{tabular}


Table 4

Alternative Measure of Unexpected Change in Cash

This table reports the relation between the deviations from optimal corporate cash holdings and the value of cash from a shareholder's perspective using an alternative measure of the unexpected change in cash. $\Delta$ Net Cash is the realized change in cash holdings minus the average change in cash holdings in the corresponding benchmark portfolio over the same period. The definition of all other variables can be found in the text and in the heading of Table 3 . We report the p-value calculated based on the robust standard errors clustered by firm in the parentheses. $* * *, * *$ and $*$ denote significance at the $1 \%, 5 \%$ and $10 \%$ level.

\begin{tabular}{|c|c|c|}
\hline \multirow[b]{2}{*}{ Intercept } & \multicolumn{2}{|c|}{ Excess Return } \\
\hline & $0.026 * * *$ & $0.027 * * *$ \\
\hline & $(0.01)$ & $(0.01)$ \\
\hline \multirow[t]{2}{*}{$\Delta$ Net Cash } & $1.390 * * *$ & $1.364 * * *$ \\
\hline & $(0.01)$ & $(0.01)$ \\
\hline \multirow[t]{2}{*}{ Towards Optimum $* \Delta$ Net Cash } & & $0.179 * * *$ \\
\hline & & $(0.01)$ \\
\hline \multirow[t]{2}{*}{$\Delta$ Earnings } & $0.702 * * *$ & $0.699 * * *$ \\
\hline & $(0.01)$ & $(0.01)$ \\
\hline \multirow[t]{2}{*}{$\Delta$ Net Assets } & $0.314 * * *$ & $0.317 * * *$ \\
\hline & $(0.01)$ & $(0.01)$ \\
\hline \multirow[t]{2}{*}{$\Delta \mathrm{R} \& \mathrm{D}$} & $0.740 * * *$ & $0.743 * * *$ \\
\hline & $(0.01)$ & $(0.01)$ \\
\hline \multirow[t]{2}{*}{$\Delta$ Interest Expenses } & $-1.519 * * *$ & $-1.520 * * *$ \\
\hline & $(0.01)$ & $(0.01)$ \\
\hline \multirow[t]{2}{*}{$\Delta$ Dividends } & $2.761 * * *$ & $2.765^{* * *}$ \\
\hline & $(0.01)$ & $(0.01)$ \\
\hline \multirow[t]{2}{*}{$\operatorname{Cash}_{\mathrm{t}-1}$} & $0.258 * * *$ & $0.264 * * *$ \\
\hline & $(0.01)$ & $(0.01)$ \\
\hline \multirow[t]{2}{*}{ Leverage } & $-0.271 * * *$ & $-0.273 * * *$ \\
\hline & $(0.01)$ & $(0.01)$ \\
\hline \multirow[t]{2}{*}{$\operatorname{Cash}_{\mathrm{t}-1} * \Delta$ Net Cash } & $-1.338 * * *$ & $-1.380 * * *$ \\
\hline & $(0.01)$ & $(0.01)$ \\
\hline \multirow[t]{2}{*}{ Leverage $* \Delta$ Net Cash } & $-0.814 * * *$ & $-0.806 * * *$ \\
\hline & $(0.01)$ & $(0.01)$ \\
\hline \multirow[t]{2}{*}{ Net Financing } & $0.121 * * *$ & $0.120 * * *$ \\
\hline & $(0.01)$ & $(0.01)$ \\
\hline Observations & 77999 & 77999 \\
\hline Adjusted R-squared & 0.12 & 0.12 \\
\hline
\end{tabular}

The following table shows the marginal value of $\$ 1$ calculated based on the estimates in the regressions.

\begin{tabular}{ll|ll}
\hline \multicolumn{4}{c}{ The marginal value of $\$ \mathbf{1}$} \\
\hline \multirow{2}{*}{ Entire sample } & Towards Optimum $=1$ & $\$ 1.15$ \\
& Towards Optimum $=0$ & $\$ 0.97$ \\
\hline
\end{tabular}




\section{Table 5}

\section{Deviations on Both Sides and the Value of Cash}

This table reports the relation between the deviations on both sides of optimal corporate cash holdings and the value of cash from a shareholder's perspective. Above is a dummy variable that equals 1 if the actual level of cash is above the predicted level of cash, and equals 0 otherwise. The definition of all other variables can be found in the text and in the headings of Table 3 and Table 4. F-test refers to an F-test on the null hypothesis that the sum of the coefficients of Towards Optimum $* \Delta$ Cash ( $\Delta$ Net Cash) and Towards Optimum $* \Delta \mathrm{Cash}(\Delta \mathrm{Net}$ Cash $) *$ Above $_{\mathrm{t}-1}$ is zero. We report the p-value calculated based on the robust standard errors clustered by firm in the parentheses. $* * *, * *$ and $*$ denote significance at the $1 \%, 5 \%$ and $10 \%$ level.

\begin{tabular}{|c|c|c|}
\hline \multirow[b]{2}{*}{ Intercept } & \multicolumn{2}{|c|}{ Excess Return } \\
\hline & $\begin{array}{c}0.008^{*} \\
(0.08)\end{array}$ & $\begin{array}{c}0.025^{* * *} \\
(0.01)\end{array}$ \\
\hline$\Delta$ Cash & $\begin{array}{c}1.381 * * * \\
(0.01)\end{array}$ & \\
\hline Towards Optimum $* \Delta$ Cash & $\begin{array}{c}0.222 * * * \\
(0.01)\end{array}$ & \\
\hline Towards Optimum $* \Delta$ Cash $*$ Above $_{\mathrm{t}-1}$ & $\begin{array}{c}-0.126^{* * *} \\
(0.01)\end{array}$ & \\
\hline$\Delta$ Net Cash & & $\begin{array}{c}1.374 * * * \\
(0.01)\end{array}$ \\
\hline Towards Optimum $* \Delta$ Net Cash & & $\begin{array}{c}0.207 * * \\
(0.05)\end{array}$ \\
\hline Towards Optimum $* \Delta$ Net Cash $*$ Above $_{\mathrm{t}-1}$ & & $\begin{array}{c}-0.079 \\
(0.50)\end{array}$ \\
\hline$\Delta$ Earnings & $\begin{array}{c}0.700 * * * \\
(0.01)\end{array}$ & $\begin{array}{c}0.701 * * * \\
(0.01)\end{array}$ \\
\hline$\Delta$ Net Assets & $\begin{array}{c}0.316^{* * * *} \\
(0.01)\end{array}$ & $\begin{array}{c}0.317 * * * \\
(0.01)\end{array}$ \\
\hline$\Delta \mathrm{R} \& \mathrm{D}$ & $\begin{array}{c}0.739 * * * \\
(0.01)\end{array}$ & $\begin{array}{c}0.739 * * * \\
(0.01)\end{array}$ \\
\hline$\Delta$ Interest Expenses & $\begin{array}{c}-1.504 * * * \\
(0.01)\end{array}$ & $\begin{array}{c}-1.518 * * * \\
(0.01)\end{array}$ \\
\hline$\Delta$ Dividends & $\begin{array}{c}2.766^{* * * *} \\
(0.01)\end{array}$ & $\begin{array}{c}2.759 * * * \\
(0.01)\end{array}$ \\
\hline $\mathrm{Cash}_{\mathrm{t}-1}$ & $\begin{array}{c}0.288 * * * \\
(0.01)\end{array}$ & $\begin{array}{c}0.271 * * * \\
(0.01)\end{array}$ \\
\hline Leverage & $\begin{array}{c}-0.267 * * * \\
(0.01)\end{array}$ & $\begin{array}{c}-0.272 * * * \\
(0.01)\end{array}$ \\
\hline $\operatorname{Cash}_{\mathrm{t}-1} * \Delta$ Cash & $\begin{array}{c}-1.400 * * * \\
(0.01)\end{array}$ & \\
\hline Leverage $* \Delta$ Cash & $\begin{array}{c}-0.795^{* * *} \\
(0.01)\end{array}$ & \\
\hline $\operatorname{Cash}_{\mathrm{t}-1} * \Delta$ Net Cash & & $\begin{array}{c}-1.363 * * * \\
(0.01)\end{array}$ \\
\hline Leverage $* \Delta$ Net Cash & & $\begin{array}{c}-0.803 * * * \\
(0.01)\end{array}$ \\
\hline Net Financing & $\begin{array}{c}0.126 * * * \\
(0.01)\end{array}$ & $\begin{array}{c}0.120 * * * \\
(0.01)\end{array}$ \\
\hline F-test (p-value) & 0.01 & 0.01 \\
\hline Observations & 77999 & 77999 \\
\hline Adjusted R-squared & 0.12 & 0.12 \\
\hline
\end{tabular}




\section{Table 5 (Continued)}

The following tables show the marginal value of $\$ 1$ calculated based on the estimates in the regressions.

\begin{tabular}{ll|lc}
\hline \multicolumn{4}{c}{ The marginal value of \$1 } \\
$(\Delta$ Cash $)$
\end{tabular}

The marginal value of $\$ 1$

$(\triangle \mathrm{Net}$ Cash)

\begin{tabular}{ll|lc}
\hline Towards Optimum $=0$ & $\$ 0.98$ & Towards Optimum $=1$ and Above $_{\mathrm{t}-1}=0$ & $\$ 1.19$ \\
& Towards Optimum $=1$ and Above $_{\mathrm{t}-1}=1$ & $\$ 1.11$
\end{tabular}


Table 6

The Magnitude of Deviations and the Value of Cash

This table reports the relation between the magnitude of deviations and the value of cash from a shareholder's perspective. Larger (Smaller) Step Towards Optimum is a dummy variable that equals 1 if the magnitude of the change in cash towards the optimum is above (below) the median, and equals 0 otherwise. After Adjustment Close To Optimum is a dummy variable that equals 1 if a firm's cash is at most $10 \%$ away from the optimum after the change, and equals 0 otherwise. Disequilibrium Reduction is a continuous variable defined as the reduction in the magnitude of deviations from the optimum. The definition of all other variables can be found in the text and in the heading of Table 3. We report the p-value calculated based on the robust standard errors clustered by firm in the parentheses. ${ }^{* *}, * *$ and $*$ denote significance at the $1 \%, 5 \%$ and $10 \%$ level.

\begin{tabular}{|c|c|c|c|}
\hline \multirow[b]{2}{*}{ Intercept } & \multicolumn{3}{|c|}{ Excess Return } \\
\hline & $\begin{array}{c}0.010 * * \\
(0.03)\end{array}$ & $\begin{array}{c}0.010^{* *} \\
(0.02)\end{array}$ & $\begin{array}{c}0.019 * * * \\
(0.01)\end{array}$ \\
\hline$\Delta$ Cash & $\begin{array}{c}1.369 * * * \\
(0.01)\end{array}$ & $\begin{array}{c}1.374 * * * \\
(0.01)\end{array}$ & $\begin{array}{c}1.517 * * * \\
(0.01)\end{array}$ \\
\hline Towards Optimum $* \Delta$ Cash & & $\begin{array}{c}0.095 * * * \\
(0.01)\end{array}$ & \\
\hline Towards Optimum $*$ Larger Step Towards Optimum $* \Delta$ Cash & $\begin{array}{c}0.197 * * * \\
(0.01)\end{array}$ & & \\
\hline Towards Optimum $*$ Smaller Step Towards Optimum $* \Delta$ Cash & $\begin{array}{c}0.116^{* *} \\
(0.03)\end{array}$ & & \\
\hline Towards Optimum * After Adjustment Close To Optimum & & $\begin{array}{c}0.580 * * * \\
(0.01)\end{array}$ & \\
\hline Disequilibrium Reduction $* \Delta \mathrm{Cash}$ & & & $\begin{array}{c}0.571 * * * \\
(0.01)\end{array}$ \\
\hline$\Delta$ Earnings & $\begin{array}{c}0.698 * * * \\
(0.01)\end{array}$ & $\begin{array}{c}0.700 * * * \\
(0.01)\end{array}$ & $\begin{array}{c}0.757 * * * \\
(0.01)\end{array}$ \\
\hline$\Delta$ Net Assets & $\begin{array}{c}0.315^{* * *} \\
(0.01)\end{array}$ & $\begin{array}{c}0.315 * * * \\
(0.01)\end{array}$ & $\begin{array}{c}0.309 * * * \\
(0.01)\end{array}$ \\
\hline$\Delta \mathrm{R} \& \mathrm{D}$ & $\begin{array}{c}0.745^{* * *} \\
(0.01)\end{array}$ & $\begin{array}{c}0.744 * * * \\
(0.01)\end{array}$ & $\begin{array}{c}0.784 * * * \\
(0.01)\end{array}$ \\
\hline$\Delta$ Interest Expenses & $\begin{array}{c}-1.508 * * * \\
(0.01)\end{array}$ & $\begin{array}{c}-1.508 * * * \\
(0.01)\end{array}$ & $\begin{array}{c}-1.571 * * * \\
(0.01)\end{array}$ \\
\hline$\Delta$ Dividends & $\begin{array}{c}2.765 * * * \\
(0.01)\end{array}$ & $\begin{array}{c}2.767 * * * \\
(0.01)\end{array}$ & $\begin{array}{c}2.682 * * * \\
(0.01)\end{array}$ \\
\hline Cash $_{t-1}$ & $\begin{array}{c}0.276^{* * * *} \\
(0.01)\end{array}$ & $\begin{array}{c}0.276 * * * \\
(0.01)\end{array}$ & $\begin{array}{c}0.302 * * * \\
(0.01)\end{array}$ \\
\hline Leverage & $\begin{array}{c}-0.269 * * * \\
(0.01)\end{array}$ & $\begin{array}{c}-0.269 * * * \\
(0.01)\end{array}$ & $\begin{array}{c}-0.279 * * * \\
(0.01)\end{array}$ \\
\hline $\operatorname{Cash}_{\mathrm{t}-1} * \Delta$ Cash & $\begin{array}{c}-1.388 * * * \\
(0.01)\end{array}$ & $\begin{array}{c}-1.380 * * * \\
(0.01)\end{array}$ & $\begin{array}{c}-1.567 * * * \\
(0.01)\end{array}$ \\
\hline Leverage $* \Delta$ Cash & $\begin{array}{c}-0.802 * * * \\
(0.01)\end{array}$ & $\begin{array}{c}-0.802 * * * \\
(0.01)\end{array}$ & $\begin{array}{c}-0.966 * * * \\
(0.01)\end{array}$ \\
\hline Net Financing & $\begin{array}{c}0.128 * * * \\
(0.01) \\
\end{array}$ & $\begin{array}{c}0.128 * * * \\
(0.01) \\
\end{array}$ & $\begin{array}{c}0.177 * * * \\
(0.01) \\
\end{array}$ \\
\hline Observations & 77999 & 77999 & 77999 \\
\hline Adjusted R-squared & 0.12 & 0.12 & 0.12 \\
\hline
\end{tabular}




\section{Table 6 (Continued)}

The following tables show the marginal value of $\$ 1$ calculated based on the estimates in the regressions.

\begin{tabular}{ll|lc}
\hline \multicolumn{5}{c}{ The marginal value of \$1 } \\
\hline \multirow{2}{*}{ Towards Optimum = } & $\$ 0.97$ & Towards Optimum = 1 and Larger Step towards Optimum = & $\$ 1.17$ \\
& Towards Optimum = 1 and Smaller Step towards Optimum = & $\$ 1.09$ \\
\hline
\end{tabular}

\section{The marginal value of $\$ 1$}

\begin{tabular}{l|ll} 
Towards Optimum $=0 \quad \$ 0.98$ & $\begin{array}{l}\text { Towards Optimum }=1 \text { and After Adjustment Close to Optimum }=1 \\
\text { Towards Optimum }=1 \text { and After Adjustment Close to Optimum }=0\end{array} \$ 1.66$
\end{tabular}

\begin{tabular}{ll}
\hline \multicolumn{2}{c}{ The marginal value of $\$ \mathbf{1}$} \\
\hline Disequilibrium Reduction $>0$ & $\$ 1.14$ \\
Disequilibrium Reduction $<0$ & $\$ 0.98$ \\
\hline
\end{tabular}




\section{Table 7}

\section{Robustness Check: Sample Period}

This table reports the robustness check. Column 1 shows the regression for the sample period from 1985 to 1995 . Column 2 shows the regression for the sample period from 1996 to 2005 . The definition of all the variables can be found in the text and in the heading of Table 3. We report the p-value calculated based on the robust standard errors clustered by firm in the parentheses. ***,** and * denote significance at the $1 \%, 5 \%$ and $10 \%$ level.

\begin{tabular}{|c|c|c|}
\hline & \multicolumn{2}{|c|}{ Excess Return } \\
\hline & $\begin{array}{c}\text { Sample Period } \\
1985-1995 \\
\end{array}$ & $\begin{array}{c}\text { Sample Period } \\
1996-2005\end{array}$ \\
\hline Intercept & $\begin{array}{c}0.018 * * * \\
(0.01)\end{array}$ & $\begin{array}{r}-0.005 \\
(0.32)\end{array}$ \\
\hline$\Delta$ Cash & $\begin{array}{c}1.017 * * * \\
(0.01)\end{array}$ & $\begin{array}{c}1.335 * * * \\
(0.01)\end{array}$ \\
\hline Towards Optimum $* \Delta$ Cash & $\begin{array}{c}0.180 * * * \\
(0.01)\end{array}$ & $\begin{array}{c}0.182 * * * \\
(0.01)\end{array}$ \\
\hline$\Delta$ Earnings & $\begin{array}{c}0.646 * * * \\
(0.01)\end{array}$ & $\begin{array}{c}0.730 * * * \\
(0.01)\end{array}$ \\
\hline$\Delta$ Net Assets & $\begin{array}{c}0.323 * * * \\
(0.01)\end{array}$ & $\begin{array}{c}0.306^{* * * *} \\
(0.01)\end{array}$ \\
\hline$\Delta \mathrm{R} \& \mathrm{D}$ & $\begin{array}{c}0.905 * * * \\
(0.01)\end{array}$ & $\begin{array}{c}0.938 * * * \\
(0.01)\end{array}$ \\
\hline$\Delta$ Interest Expenses & $\begin{array}{c}-1.441 * * * \\
(0.01)\end{array}$ & $\begin{array}{c}-1.546^{* * * *} \\
(0.01)\end{array}$ \\
\hline$\Delta$ Dividends & $\begin{array}{c}2.696 * * * \\
(0.01)\end{array}$ & $\begin{array}{c}2.727 * * * \\
(0.01)\end{array}$ \\
\hline $\mathrm{Cash}_{\mathrm{t}-1}$ & $\begin{array}{c}0.188 * * * \\
(0.01)\end{array}$ & $\begin{array}{c}0.295 * * * \\
(0.01)\end{array}$ \\
\hline Leverage & $\begin{array}{c}-0.237 * * * \\
(0.01)\end{array}$ & $\begin{array}{c}-0.254 * * * \\
(0.01)\end{array}$ \\
\hline $\operatorname{Cash}_{\mathrm{t}-1} * \Delta$ Cash & $\begin{array}{c}-0.156 * * \\
(0.03)\end{array}$ & $\begin{array}{c}-1.479 * * * \\
(0.01)\end{array}$ \\
\hline Leverage $* \Delta$ Cash & $\begin{array}{c}-0.237 * * \\
(0.05)\end{array}$ & $\begin{array}{c}-0.583^{* * *} \\
(0.01)\end{array}$ \\
\hline Net Financing & $\begin{array}{c}0.122 * * * \\
(0.01)\end{array}$ & $\begin{array}{c}0.065 * * * \\
(0.01)\end{array}$ \\
\hline Observations & 35194 & 42805 \\
\hline Adjusted R-squared & 0.12 & 0.13 \\
\hline
\end{tabular}

The following table shows the marginal value of $\$ 1$ calculated based on the estimates in the regressions.

\begin{tabular}{ccc}
\hline & The marginal value of $\mathbf{~} \mathbf{1}$ & \\
\hline & $\begin{array}{c}\text { Sample Period } \\
1985-1995\end{array}$ & $\begin{array}{c}\text { Sample Period } \\
1996-2005\end{array}$ \\
\hline Towards Optimum $=1$ & $\$ 1.11$ & $\$ 1.16$ \\
Towards Optimum $=0$ & $\$ 0.94$ & $\$ 0.98$ \\
\hline
\end{tabular}




\section{Table 8}

\section{Robustness Check: Alternative Measure of the Dependent Variable}

This table reports the robustness check. The dependent variable is Excess Change in Tobin's Q, which is the difference between the change in a firm's Tobin's $Q$ and the benchmark change in Tobin's Q (see text for more details). The definition of all other variables can be found in the text and in the heading of Table 3. F-test refers to an F-test on the null hypothesis that the sum of the coefficients of Towards Optimum $* \Delta$ Cash and Towards Optimum $* \Delta$ Cash $*$ Above $_{\mathrm{t}-1}$ is zero. We report the p-value calculated based on the robust standard errors clustered by firm in the parentheses. $* * *$, ** and * denote significance at the $1 \%, 5 \%$ and $10 \%$ level.

\begin{tabular}{|c|c|c|}
\hline \multirow[b]{2}{*}{ Intercept } & \multicolumn{2}{|c|}{ Excess Change in Tobin's Q } \\
\hline & $\begin{array}{c}-0.376 * * * \\
(0.01)\end{array}$ & $\begin{array}{c}-0.377 * * * \\
(0.01)\end{array}$ \\
\hline$\Delta$ Cash & $\begin{array}{c}0.332 * * * \\
(0.01)\end{array}$ & $\begin{array}{c}0.332 * * * \\
(0.01)\end{array}$ \\
\hline Towards Optimum $* \Delta$ Cash & $\begin{array}{c}0.119 * * \\
(0.02)\end{array}$ & $\begin{array}{c}0.131 * * \\
(0.05)\end{array}$ \\
\hline Towards Optimum $* \Delta$ Cash $*$ Above $_{\mathrm{t}-1}$ & & $\begin{array}{r}-0.043 \\
(0.79)\end{array}$ \\
\hline$\Delta$ Earnings & $\begin{array}{c}0.400 * * * \\
(0.01)\end{array}$ & $\begin{array}{c}0.400 * * * \\
(0.01)\end{array}$ \\
\hline$\Delta$ Net Assets & $\begin{array}{c}-0.154 * * * \\
(0.01)\end{array}$ & $\begin{array}{c}-0.154 * * * \\
(0.01)\end{array}$ \\
\hline$\Delta \mathrm{R} \& \mathrm{D}$ & $\begin{array}{c}-0.331 * * \\
(0.04)\end{array}$ & $\begin{array}{c}-0.331 * * \\
(0.04)\end{array}$ \\
\hline$\Delta$ Interest Expenses & $\begin{array}{c}-0.454 * * * \\
(0.01)\end{array}$ & $\begin{array}{c}-0.454 * * * \\
(0.01)\end{array}$ \\
\hline$\Delta$ Dividends & $\begin{array}{c}3.956 * * * \\
(0.01)\end{array}$ & $\begin{array}{c}3.957 * * * \\
(0.01)\end{array}$ \\
\hline Cash $_{t-1}$ & $\begin{array}{c}0.841 * * * \\
(0.01)\end{array}$ & $\begin{array}{c}0.840 * * * \\
(0.01)\end{array}$ \\
\hline Leverage & $\begin{array}{c}0.314 * * * \\
(0.01)\end{array}$ & $\begin{array}{c}0.314 * * * \\
(0.01)\end{array}$ \\
\hline $\mathrm{Cash}_{\mathrm{t}-1} * \Delta$ Cash & $\begin{array}{c}-0.296 * * * \\
(0.01)\end{array}$ & $\begin{array}{c}-0.297 * * * \\
(0.01)\end{array}$ \\
\hline Leverage $* \Delta$ Cash & $\begin{array}{c}-0.349 * * * \\
(0.01)\end{array}$ & $\begin{array}{c}-0.349 * * * \\
(0.01)\end{array}$ \\
\hline Net Financing & $\begin{array}{l}0.002 \\
(0.94)\end{array}$ & $\begin{array}{l}0.002 \\
(0.94)\end{array}$ \\
\hline F-test (p-value) & & 0.07 \\
\hline Observations & 77999 & 77999 \\
\hline Adjusted R-squared & 0.03 & 0.03 \\
\hline
\end{tabular}

